\title{
Morphometric and pheromonal analyses of Apis mellifera $L$ along a transect from the Sahara to the Pyrenees
}

\author{
HR Hepburn 1, SE Radloff 2 \\ 1 Department of Zoology and Entomology; \\ 2 Department of Statistics, Rhodes University, Grahamstown 6140, South Africa
}

(Received 30 July 1995; accepted 15 January 1996)

\begin{abstract}
Summary - Pheromones and morphological characteristics of worker honeybees from Morocco and Spain were analyzed with multivariate statistical methods. Principal component and stepwise discriminant analyses yieided three morphological clusters, corresponding to sahariensis and intermissa (including the ecotype major) in Morocco and to iberica (with three biometric populations) in Spain, but no pheromone clusters. Inter-colonial variances for all characteristics formed significant asymmetries within the areas of classically defined subspecies. These were complemented by trends in intra-colonial variance. The combined morphometric and pheromonal variance spectra indicate regions of natural hybridization along a Sahara-Pyrenees transect.
\end{abstract}

honeybee / population genetics / morphometrics / pheromone / N Africa / Spain

\section{INTRODUCTION}

Honeybees native to the Maghreb derive from a common African lineage which now coexists with the western European lineage on the Iberian peninsula (Ruttner, 1988; Smith et al, 1991; Cornuet and Garnery, $1991 a, b)$. The former are classified as the races sahariensis, intermissa and major (Cornuet et al, 1988; Ruttner, 1988) and the latter as iberica (Goetze, 1964; Ruttner, 1988). However, biometric subgroups have been identified for both intermissa (Lebdi-Grissa et al, 1991) and iberica (Cornuet and Fres- naye, 1989; Orantes-Bermejo and GarciaFernandez, 1995). There is also concommitant variation in the mtDNA haplotypes (Garnery et al, 1995) and allozyme alleles (Smith and Glenn, 1994) for all four races.

Because the honeybees between the Sahara and the Pyrenees do not form a single panmictic population, as already shown by their biometric groups, both differentiation and hybridization can be expected (Cornuet et al, 1988; Garnery et al, 1995). It is also somewhat problematic that the bees of Morocco and Spain have not been combined in a single comparative study using 
the same suites of characters, localities and methods of statistical discrimination. Thus we have morphometrically and pheromonally analyzed samples of honeybees collected from colonies along a transect through this region to determine their heteroscedasticity characteristics and to identify possible zones of hybridization.

\section{MATERIALS AND METHODS}

Morphometric measurements were made on at least ten worker bees per colony, and five or six colonies were sampled at each location (fig 1). A total of 743 bees were used in the morphometric analyses. Eleven characters, all based on the Oberursel standard list, except the angle MJI (see Ruttner, 1988; page 73, fig 6.9), were measured; they were, with their Ruttner identification numbers given in brackets: length of cover hair on tergite 5 (1), pigment of scutellum (35), pigment of scutellum plate (36), wing angle B4 (22), angle MJI, angle N23 (30), angle O26 (31), length of proboscis (4), length of sternite $3(11)$, transverse length wax plate of sternite 3 (13) and pigment of tergite 2 (32).

For the pheromone analyses five guard bees were collected from each of five or six colonies per location; a total of 370 bees were used in the analysis. Mandibular gland extracts were concentrated with nitrogen and derivatized with BSTFA; sting samples were not treated. All samples were measured with a Hewlett-Packard 5890 Series II gas chromatograph fitted with a bonded methyl silicone fused silica capillary column $(0.3$ $\mathrm{mm} \times 25 \mathrm{~m}$ ) and quantified with an HP 3396 Series II integrator calibrated with authentic standards of both mandibular gland and sting pheromone compounds.

Multivariate statistical analysis of the data included principal component analysis, factor analysis and linear discriminant analysis. Wilks' lambda test was used to compare multivariate population means between groups. The distribution of the $\Lambda$ statistic was approximated by the $F$ distribution (Mardia et al, 1979). Levene's $F$ statistic for testing the equality of the variances between groups was also used in the analysis. This test procedure is based on an analysis of variance using the absolute deviation of each case from its cell mean (Brown and Forsythe, 1974). The sequential Bonferroni method of multiple tests of individual significance of correlations was used to ensure that the overall level of significance was not larger than 0.05 (Miller, 1981). In the morphometric analysis separate analyses were carried out on the colony means, standard deviations and covariances of the eleven chracteristics. For the pheromone analyses the colony mean percentages, standard deviations and covariances of the eight pheromone compounds were analyzed.

\section{RESULTS}

\section{Morphometric analysis}

In a principal component analysis of the morphometric characters of 73 colonies, three factors with eigenvalues $>1$ were isolated: factor 1, characters associated with size (13), (11), (4), (1) and pigmentation (32); factor 2, pigmentation (35) and (36); and factor 3 , angles of venation MJl and (22). These factors accounted for $71.2 \%$ of the variance in the data. The loading for each character had an absolute value greater than 0.70 . The graph of the scores from factors 1 and 2 showed three clusters (fig 2).

A stepwise discriminant analysis using the colony means of the morphometric characters confirmed the separation of the three clusters. Table I shows the five characters

Table I. Morphological characters entered into the discriminant function ranked according to their discriminatory power.

$\begin{array}{crcr}\text { Character }^{a} & \text { F statistic } & d f & p \text {-value } \\ & & & \\ (32) & 433.59 & 2,70 & <0.0001 \\ (11) & 124.04 & 2,69 & <0.0001 \\ (30) & 8.23 & 2,68 & 0.0006 \\ (31) & 6.05 & 2,67 & 0.0038 \\ (1) & 7.59 & 2,66 & 0.0011\end{array}$

a Ruttner number as described in the text. 


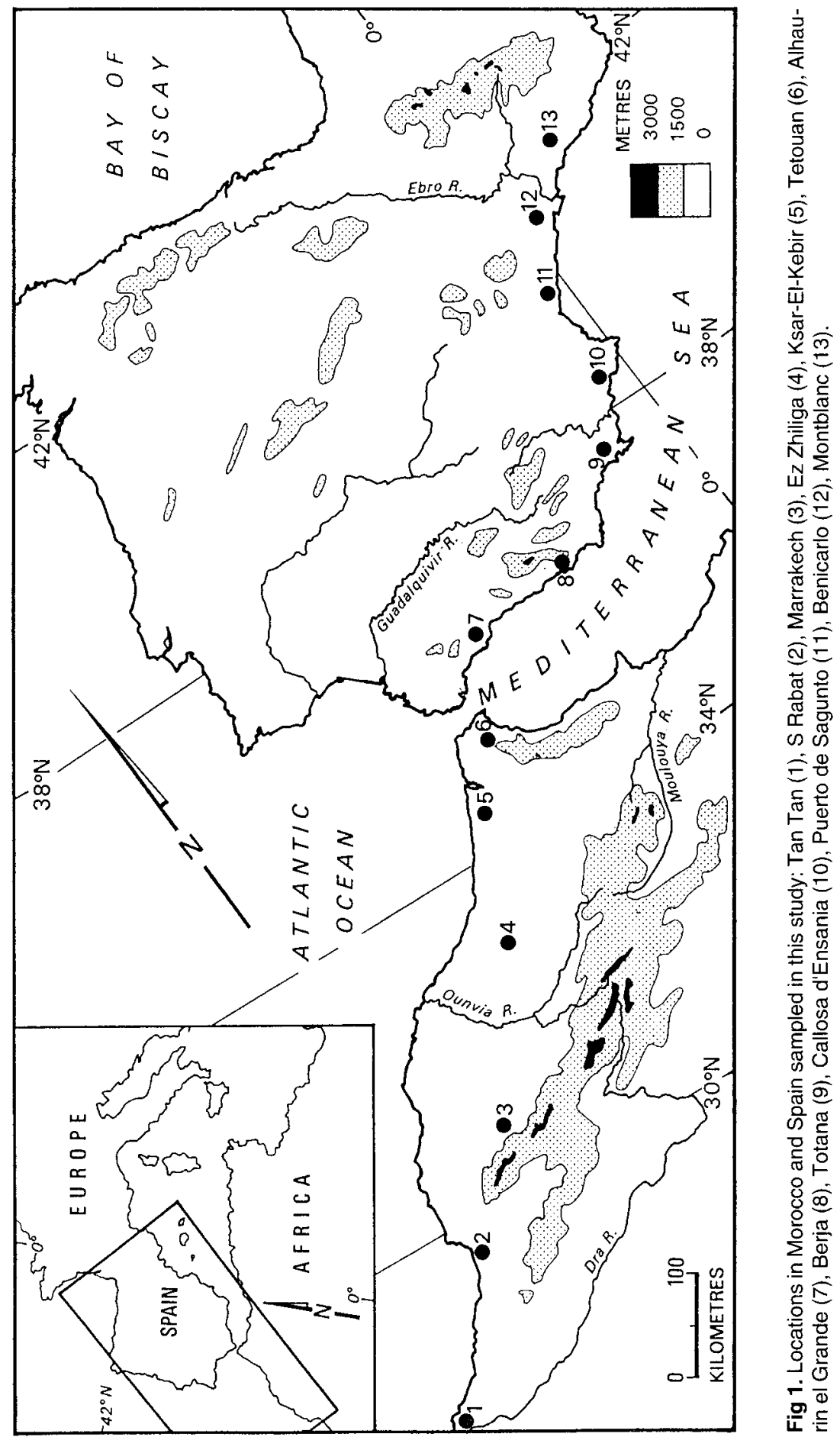




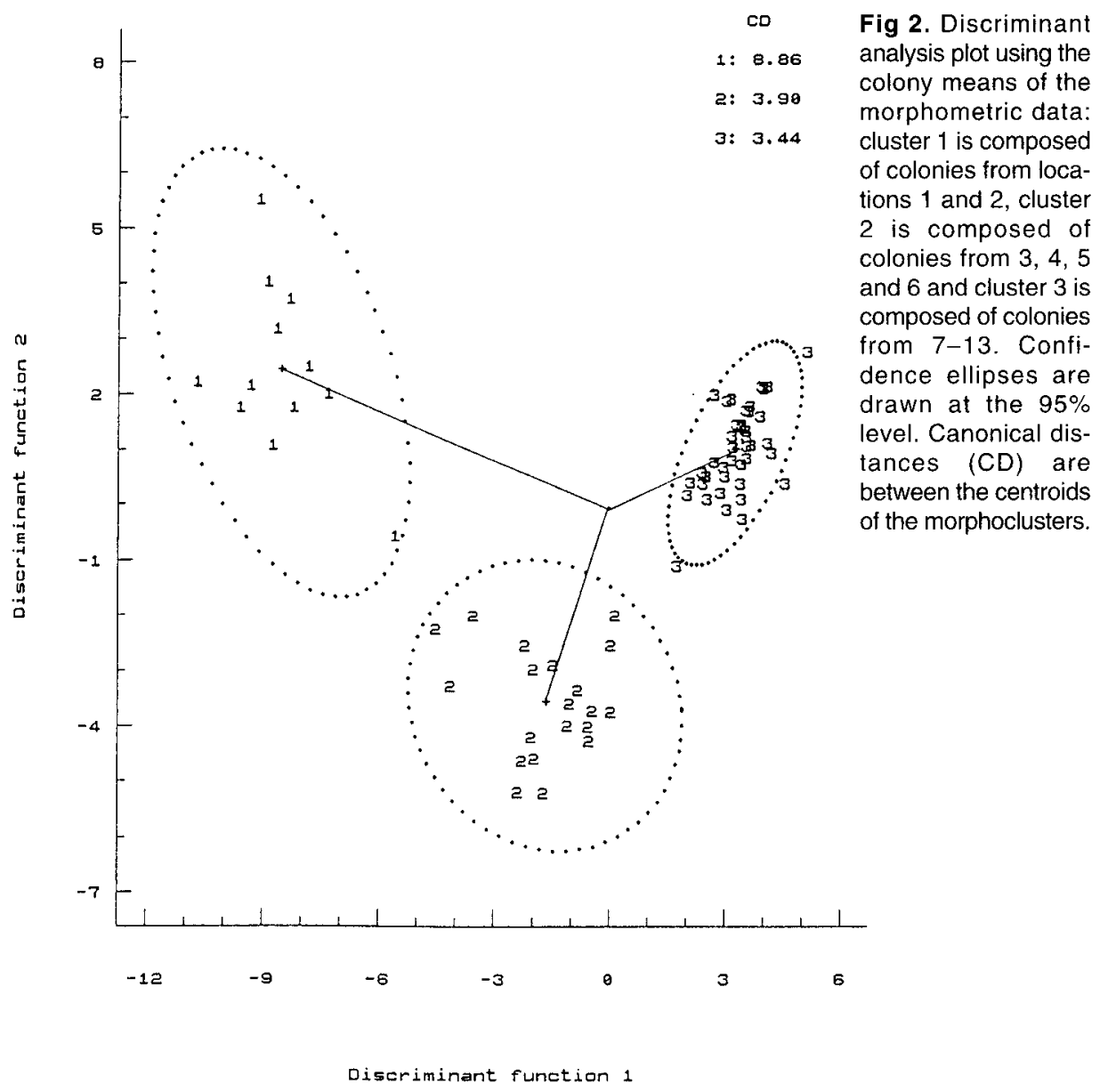

entered into the linear discriminant functions ranked according to their discriminatory power. Each colony was assumed to have equal prior probability of being in any cluster. A discriminant analysis using the means of the most discriminatory characters was carried out and $100 \%$ correct classification into the three established clusters was obtained (fig 2).

Mahalanobis distances $D^{2}$ between the clusters were $D^{2}=24.14$ for clusters 1 and $2,83.97$ for 1 and 3 , and 14.62 for 2 and 3 . In group 1, $100 \%$ of the colonies were classified correctly, with posterior probabilities of
$P=1.0$ for 11 colonies and 0.934 for the remaining colony. In group $2,100 \%$ of the colonies were classified correctly, with posterior probabilities of $P=1.0$ for 19 colonies and 0.997 for the other one, and in group 3 , $100 \%$ correct classification was established, with posterior probabilities of $P=1.0$ for 40 colonies and 0.980 for the remaining colony. A jackknife procedure (Lachenbruch and Mickey, 1968) produced identical classification results.

To test for the equality of the group means for the characters used in the discriminant function, Wilks' lambda approxi- 
Table II. Means and standard deviations of discriminant morphometric characters (lengths in $\mathrm{mm}$, angles in degrees).

\begin{tabular}{|c|c|c|c|c|c|c|}
\hline Charactera & \multicolumn{2}{|c|}{$\begin{array}{l}\text { Group } 1 \\
\mathrm{n}=120\end{array}$} & \multicolumn{2}{|c|}{$\begin{array}{l}\text { Group } 2 \\
n=213\end{array}$} & \multicolumn{2}{|c|}{$\begin{array}{c}\text { Group } 3 \\
\mathrm{n}=410\end{array}$} \\
\hline (1) & 0.19 & $(0.027)$ & 0.22 & $(0.046)$ & 0.29 & $(0.063)$ \\
\hline (4) & 6.07 & $(0.167)$ & 6.26 & $(0.278)$ & 6.57 & $(0.182)$ \\
\hline (11) & 2.70 & $(0.072)$ & 2.73 & $(0.092)$ & 2.95 & $(0.071)$ \\
\hline (13) & 2.24 & $(0.074)$ & 2.30 & $(0.105)$ & 2.49 & $(0.061)$ \\
\hline (22) & 106.20 & $(6.808)$ & 106.52 & (6.744) & 107.73 & (5.194) \\
\hline MJI & 19.10 & $(2.767)$ & 18.95 & (2.393) & 18.48 & $(2.330)$ \\
\hline (30) & 79.24 & $(5.242)$ & 75.59 & (6.421) & 81.54 & $(4.505)$ \\
\hline (31) & 34.24 & (3.233) & 35.16 & $(4.417)$ & 37.90 & $(3.367)$ \\
\hline$(32)$ & 7.36 & (2.172) & 1.87 & $(1.254)$ & 1.23 & $(0.505)$ \\
\hline (35) & 2.77 & (1.704) & 0.15 & $(0.411)$ & 0.39 & $(0.493)$ \\
\hline (36) & 0.38 & $(0.900)$ & 0.19 & $(0.501)$ & 0.57 & $(0.747)$ \\
\hline
\end{tabular}

a Ruttner number as described in the text.

mated by the $F$ statistic was determined. A significant difference between the means of the three groups was established $(\Lambda=$ $0.0090,5,2,70 \mathrm{df}, F=125.86,10,132 \mathrm{df}$, $P<0.0001)$. The means and standard deviations of the 11 morphometric characters are shown in table II for the three groups using all 743 bees from the 13 locations.

A factor analysis was carried out using the colonies from Spain in order to investigate any morphological differences between the different locations. Three biometric groups were found, group A comprising colonies from location 7, group B comprising colonies from locations $8,9,10$ and 11 , and group $\mathrm{C}$ comprising colonies from 12 and 13 (fig 1). A discriminant analysis confirmed these three biometric groups, with $100 \%$ correct classification results in each group apart from one group $\mathrm{B}$ colony being classified as group $\mathrm{C}$ (fig 3 ).

The first principal component coefficients of the morphometric characters were used to determine the factor score of each bee. The variances of these factor scores were used to test for homogeneity of the vari- ances at each location. A significant difference was found between the intra-colonial variances (table IV) over all the locations (Levene's test $F=4.54$ with $12,730 \mathrm{df}, P<$ $0.0001)$. When the variances were tested in pairs between locations it was found that the variances obtained at Tan Tan, S Rabat, Ksar-El-Kebir and Tetouan in Morocco were significantly different from those at Berja in southern Spain through to Montblanc in northeastern Spain.

A significant difference was also established between Montblanc and the other Spanish localities north of Berja (Levene's test in each case gave $P<0.001$, which is significant when using Bonferroni's adjustment to the level of significance for simultaneous testing). The inter-colonial variances (table IV) were computed by the same method but this time the colony means were used to determine the factor scores of each colony. No significant difference was found in the variances between locations $(F=1.57$ with $12,60 \mathrm{df}, P=0.1239$ ). However, larger variances were again obtained at Tan Tan, Ksar-El-Kebir and Tetouan. 


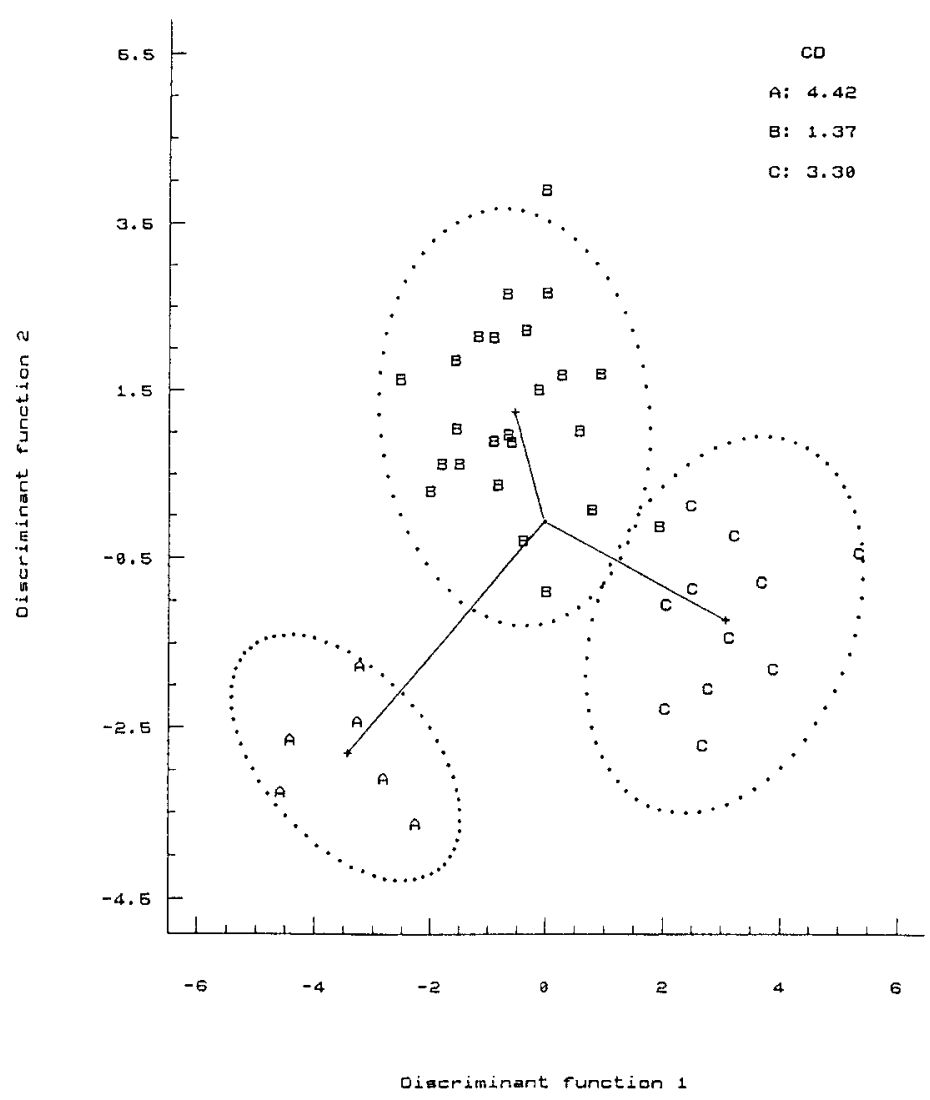

Fig 3. Discriminant analysis plot of the colonies in Spain using the means of the morphometric data. Biometric group $A$ is composed of colonies from locality 7 , biometric group $B$ is composed of colonies from 8-11 and biometric group $\mathrm{C}$ is composed of colonies from 12 and 13. Confidence ellipses are drawn at the $90 \%$ level. Canonical distances (CD) are between the centroids of the biometric groups.

\section{Pheromone analysis}

\section{Sting pheromones}

In a principal component analysis using the mean percentages of the eight compounds (table III) of the sting pheromone complex, the following three factors with eigenvalues $>1$ were isolated and accounted for $70.4 \%$ of the variance of the data: factor $1:(3)$ and (2); factor 2: (1), (7) and (6); factor 3: (4) and (5). The factor scores plot revealed no distinct clusters. The discriminant analysis procedure using the colony means produced $100 \%$ correct classification in group 1 , $73.33 \%$ correct classification in group 2 and $75.00 \%$ correct classification in group 3 .
Table III shows the percentages of the different pheromone compounds for each of the three groups.

To test for heteroscedasticity in the variances of the sting pheromone percentages between locations, the first principal component coefficients of the standardized percentages were calculated and used to determine the factor score of each bee. A significant difference between the intra-colonial variances (table IV) of these factor scores was found between the locations (Levene's test $F=4.56,12,351 \mathrm{df}, P<$ $0.0001)$. Multiple comparison tests showed that the variances of the pheromone percentages at Tan Tan, Marrakech and Puerto de Sagunto were significantly different from 
Table III. Mean percentages and standard deviations of the sting and mandibular gland pheromones.

\begin{tabular}{|c|c|c|c|c|c|c|}
\hline Pheromones & & $\begin{array}{l}u p 1 \\
60\end{array}$ & & $\begin{array}{l}u p 2 \\
105\end{array}$ & & $\begin{array}{l}\text { up } 3 \\
205\end{array}$ \\
\hline Sting & & & & & & \\
\hline isopentyl alcohol (1) & 4.32 & $(4.51)$ & 6.63 & (6.69) & 11.10 & (15.94) \\
\hline$n$-butyl acetate (2) & 4.03 & $(4.90)$ & 3.60 & (3.15) & 1.00 & $(2.85)$ \\
\hline isopentyl acetate (3) & 15.19 & (10.73) & 25.03 & (13.99) & 13.86 & (10.56) \\
\hline benzyl alcohol (4) & 5.48 & $(7.52)$ & 5.07 & $(4.30)$ & 4.42 & $(5.32)$ \\
\hline n-octyl acetate (5) & 2.03 & (3.43) & 6.12 & $(5.22)$ & 20.11 & (19.37) \\
\hline 2-nonanol (6) & 27.62 & (8.03) & 23.58 & (13.50) & 24.67 & (16.50) \\
\hline benzyl acetate (7) & 10.64 & $(9.22)$ & 8.71 & $(5.62)$ & 6.04 & $(5.29)$ \\
\hline$n$-decyl acetate (8) & 30.70 & $(27.07)$ & 21.26 & (17.56) & 18.82 & $(17.12)$ \\
\hline Mandible & & & & & & \\
\hline methyl 4 hydroxybenzoate (1) & 40.76 & $(11.33)$ & 26.89 & (10.32) & 26.18 & $(12.46)$ \\
\hline 4-hydroxybenzoic acid (2) & 3.42 & $(2.33)$ & 1.88 & $(1.67)$ & 3.20 & (1.29) \\
\hline dodecanoic acid (3) & 3.45 & $(2.27)$ & 0.72 & $(0.88)$ & 2.18 & (1.12) \\
\hline (E)-9-ketodecen-2-enoic acid (4) & 1.68 & $(1.06)$ & 1.23 & $(1.42)$ & 1.39 & $(0.81)$ \\
\hline 2-(4-hydroxy-3-methoxy) ethanol (5) & 3.71 & (2.90) & 4.77 & (3.12) & 4.99 & $(2.77)$ \\
\hline tetradecanoic acid (6) & 2.64 & $(0.79)$ & 4.16 & (3.38) & 5.45 & (2.39) \\
\hline 10-hydroxydecanoic acid (7) & 43.99 & $(10.00)$ & 60.23 & (11.32) & 56.02 & $(11.25)$ \\
\hline hexadecanoic acid (8) & 0.35 & (1.14) & 0.10 & $(0.28)$ & 0.60 & $(0.96)$ \\
\hline
\end{tabular}

Table IV. Intra-colonial and inter-colonial variances of factor scores of the morphometric and pheromone data at each location.

\begin{tabular}{|c|c|c|c|c|c|c|}
\hline \multirow[t]{2}{*}{ Locality } & \multicolumn{2}{|c|}{ Morphology } & \multicolumn{2}{|c|}{ Stings } & \multicolumn{2}{|c|}{ Mandible } \\
\hline & $\begin{array}{c}\text { Intra- } \\
\text { colonial }\end{array}$ & $\begin{array}{l}\text { Inter- } \\
\text { colonial }\end{array}$ & $\begin{array}{l}\text { Intra- } \\
\text { colonial }\end{array}$ & $\begin{array}{c}\text { Inter- } \\
\text { colonial }\end{array}$ & $\begin{array}{c}\text { Intra- } \\
\text { colonial }\end{array}$ & $\begin{array}{c}\text { Inter- } \\
\text { colonial }\end{array}$ \\
\hline Tan Tan & 9.43 & 6.45 & 2.51 & 2.55 & 5.38 & 4.14 \\
\hline S Rabat & 11.25 & 2.19 & 0.34 & 0.48 & 8.08 & 6.43 \\
\hline Marrakech & 6.72 & 2.75 & 3.76 & 3.47 & 3.16 & 3.16 \\
\hline Ez Zhiliga & 6.08 & 4.07 & 1.34 & 1.57 & 2.47 & 3.27 \\
\hline Ksar-El-Kebir & 10.44 & 5.15 & 1.45 & 1.23 & 1.04 & 2.27 \\
\hline Tetouan & 10.87 & 9.21 & 0.86 & 0.39 & 1.63 & 0.71 \\
\hline Alhaurin el Grande & 5.21 & 3.73 & 1.65 & 2.08 & 4.69 & 2.57 \\
\hline Berja & 3.13 & 0.76 & 0.55 & 0.69 & 2.72 & 2.01 \\
\hline Totana & 3.57 & 0.37 & 1.56 & 2.37 & 2.18 & 2.91 \\
\hline Callosa d'Ensania & 3.22 & 3.11 & 1.33 & 0.78 & 2.25 & 1.58 \\
\hline Puerto de Sagunto & 3.87 & 2.01 & 2.64 & 1.62 & 7.60 & 3.51 \\
\hline Benicarlo & 3.77 & 3.00 & 0.70 & 0.96 & 3.62 & 2.83 \\
\hline Montblanc & 6.09 & 1.81 & 1.38 & 0.50 & 2.63 & 3.28 \\
\hline
\end{tabular}


the variances at the other localities $(P<$ 0.0272 in each case). No significant difference was found between the inter-colonial variances (table IV) between locations ( $F=$ $1.37,12,61 \mathrm{df}, P=0.2066)$. However it was noted that the inter-colonial variations were again higher at Tan Tan and Marrakech.

\section{Mandibular gland pheromones}

The factor analysis of the mean percentages of the eight mandibular gland pheromones (table III) revealed the following three factors that accounted for $70.0 \%$ of the variance: factor 1: (1) and (7); factor 2: (2), (3) and (5); factor 3: (4) and (6). The factor scores plot revealed no distinct clusters. The discriminant analysis procedure using the colony means gave $83.33 \%$ correct classification in group $1,71.43 \%$ correct classification in group 2 and $60.98 \%$ correct classification in group 3. Table III presents the percentages of the different pheromone compounds for each of the three groups.

Levene's test for homogeneity of the variances of the mandibular gland pheromone percentages between locations showed a significant difference in the intra-colonical variance $(F=1.86,12,322 \mathrm{df} ; P=0.0390)$. Larger variances were found at Tan Tan, $S$ Rabat and Puerto de Sagunto (table IV). No significant difference was found in the inter-colonial variances between the different location $(F=1.15,12,61 \mathrm{df}, P=0.3422)$ though larger variances were established at Tan Tan and S Rabat.

\section{DISCUSSION}

The principal component and discriminant function analyses delineated three morphometrically distinct clusters (fig 2) and three biometric groups for cluster 3 (fig 3 ) along the Sahara to Pyrenees transect (fig 1). These results differ somewhat from those of Ruttner (1988) and Cornuet et al (1988) in the appearance of two distinct clusters in their single cluster intermissa region. The single cluster for Spain matches that of Goetze (1964) and Ruttner (1988) and the three biometric groups correspond to those described by Cornuet and Fresnaye (1989) and Orantes-Bermejo and Garcia-Fernandez (1995).

The clusters of figure 2 and biometric groups of figure 3 were derived from somewhat different character suites and locations from those sampled by the cited authors, so some fine differences in group resolution are to be expected. The clusters of figure 2 correspond with the current classification of races for this region (Ruttner, 1988) as follows: group 1 is sahariensis, group 2 is intermissa and group 3 is iberica. The race major was not distinct in the analysis and may be regarded as an ecotype of intermissa (cf Ruttner, 1988; Kerr, 1992). The biometric groups of Spain (fig 3) are regarded as populations of iberica.

The principal component analyses of the sting and mandibular gland pheromones yielded no clusters. However it is noteworthy that both 2-nonanol and isopentyl alcohol (from the sting pheromone) are distributed along the full length of the transect (table III). The former is considered a dominant note of the African pheromonal bouquet, the latter of European races (Blum and Fales, 1988). The distribution of these genetic markers is consistent with the interpretation of a secondary contact between the African and western European lineages in this area (Garnery et al, 1992).

The differences between the clusters (fig 2) and biometric groups (fig 3) are not evenly reflected in their variance spectra (table IV). Likewise, there are significant differences between the inter-colonial variances for the ratios of the constituents in the bouquets of both mandibular and sting gland pheromones (table IV) within, but not between, localities. The high inter-colonial 
variances are also reflected in virtually mirrorimage fashion at the intra-colonial level (table IV). The latter values are interpreted as probably the result of multiple matings of queens with drones of differing allelic frequencies (Moritz and Southwick, 1992).

Collectively the variance differences form important asymmetries indicative of hybridization between the races along the transect (Moritz and Kauhausen, 1984). The variance data (table IV) indicate four highly probable zones of hybridization: (1) in southern Morocco, location 2, hybridization between sahariensis and intermissa; (2) in northern Morocco, location 6, hybridization between intermissa and ecotype major, (3) in southern Spain, location 7, hybridization between intermissa $x$ ecotype major and iberica; and (4) in northern Spain, location 13 , hybridization between iberica and me/lifera.

The probability of correctly identifying areas of hybridization based on relatively few colonies for each location sampled could be affected by the relatedness of the queens. Here we followed the advice of Ruttner (1988): the more primitive the beekeeper, the purer the race. In this case 'primitive' means the enlargement of an apiary by trapping feral/wild swarms. All samples were collected from beekeepers who simply put swarms into unmanaged, frameless, straw hives (Morocco) or home-made, unmanaged boxes (Spain). We conclude that the likelihood of such simple apiaries being the products of only a few queen mothers is extremely remote.

Because morphological characteristics generally have a low heritability (Falconer, 1989; Moritz and Southwick, 1992) additional confidence in the hybridization areas defined here derives from the heritability characteristics of the two groups of pheromones. The constituents of the pheromones are highly genetically correlated and have high degrees of heritability (Collins et al, 1987; Moritz and Hillesheim,
1985). They also typically exhibit high variances in hybrid crosses between selected lines (Boch and Rothenbuhler, 1974) as well as between races (Collins et al, 1989). Finally, similar results have been obtained in other parts of Africa in the characterization of well defined races and their areas of natural hybridization (Hepburn et al, 1994; Radloff et al, 1996).

\section{ACKNOWLEDGMENTS}

We thank DR Smith and JM Cornuet for copies of manuscripts in press, JM Cornuet and RFA Moritz for comments on this manuscript, RM Crewe for the gift of chemical standards, GE Jones and S Ranchhod for technical assistance and especially DJ Hepburn for collection of the honeybees.

\section{Résumé - Analyse morphométrique et phéromonale d'Apis mellifera $\mathrm{L}$ le long d'un transect allant du Sahara aux Pyré-} nées. Des échantillons d'abeilles ont été prélevés en 13 localités le long d'un transect partant du nord-ouest du Sahara et allant jusqu'au sud-est des Pyrénées (fig 1). Les moyennes des caractères morphométriques et de la composition chimique des phéromones ont été analysées par des méthodes statistiques multivariées afin de déterminer le domaine de variance des populations indépendamment de leur appartenance raciale. Une analyse en composantes principales et une analyse discriminante ont montré trois groupes principaux nettement délimités (fig 2), qui appartiennent aux races sahariensis, intermissa (y compris l'écotype major) et iberica. Au sein de la race iberica on peut distinguer trois populations différentes d'un point du vue biométrique (fig 3). Le tableau II donne les moyennes des caractères morphométriques pour chacun des groupes. Tandis qu'une analyse en composantes principales ne regroupe pas les données des phéromones de l'aiguillon et de la glande mandibulaire, 
l'analyse discriminante délimite des groupes nets pour les deux phéromones (tableau III). Les variances inter-colonies des données morphométriques et des données des glandes mandibulaires et de l'aiguillon ne sont pas significativement différentes d'une localité à une autre, mais il existe des différences significatives au sein d'une même localité (tableau IV). Les différences entre les groupes principaux (fig 2) et les populations biométriques (fig 3 ) ne se retrouvent pas de façon analogue dans leurs spectres de variance (tableau IV). Les variances intercolonies des proportions relatives des composés phéromonaux étaient significativement différentes (tableau IV). D'après l'étude de la variance il existe vraisemblablement quatre zones d'hybridation (fig 1) : la localité 2 entre sahariensis et intermissa; la localité 6 entre intermissa et l'écotype major; la localité 7 entre l'écotype major et iberica; la localité 13 entre iberica et mellifera.

\section{génétique population / morphométrie / phéromone / Afrique du Nord / Espagne}

\section{Zusammenfassung - Morphometrische und Pheromonanalyse von Apis melli-} fera entlang einer Schnittlinie von der Sahara bis zu den Pyrenäen. An 13 Orten entlang einer von der nordwestlichen Sahara bis zu den südöstlichen Pyrenäen reichenden Schnittlinie wurden Honigbienenproben gesammelt (Abb 1). Meßwerte der morphometrischen Merkmale und der Pheromonzusammensetzung wurden mit multivariaten statistischen Methoden untersucht, um das Varianzspektrum der Populationen unabhängig von der Rassezugehörigkeit zu erfassen. Eine Analysis der Hauptkomponenten- und der Diskriminanzfunktionen zeigten drei klar abgegrenzte Hauptgruppen (Abb 2), die den Rassen Sahariensis, Intermissa (einschließlich des Ökotyps Major) und Iberica zuzuordnen sind. Innerhalb der Rasse Iberica waren drei Populationen biometrisch unterscheid- bar (Abb 3). Tabelle II zeigt die Mittelwerte der morphometrischen Merkmale für die einzelnen Gruppen. Während Stachel- und Mandibeldrüsenpheromone sich in einer Hauptkomponentenanalyse nicht gruppierten, ergab eine Diskriminanzanalyse klare Gruppen für beide Pheromone (Tabelle III). Zwischen den Sammelorten waren die interkolonialen Varianzen der morphometrischen und der Stachel- und Mandibeldrüsendaten nicht signifikant unterschiedlich, allerdings gab es signifikante Unterschiede innerhalb der Sammelorte (Tabelle IV). Die Unterschiede zwischen den Hauptgruppen (Abb 2) und den biometrischen Populationen (Abb 3) spiegeln sich nicht gleichartig in ihren Varianzspektren wieder (Tabelle IV). Die interkolonialen Varianzen der relativen Anteile der Pheromonkomponenten waren ebenfalls innerhalb der Sammelorte, aber nicht zwischen diesen signifikant unterschiedlich (Tabelle IV). Nach Untersuchung der Varianz sind vier Hybridisierungszonen sehr wahrscheinlich (Abb 1); Sammelort 2 zwischen Sahariensis und Intermissa; Sammelort 6 zwischen Intermissa und Ökotyp Major, Sammelort 7 zwischen Ökotyp Major und Iberica; Sammelort 13 zwischen Iberica und Mellifera.

Honigbienen / Populationen / Morpho-
metrie / Pheromone / Nordafrika / Spanien

\section{REFERENCES}

Blum MS, Fales HM (1988) Chemical releasers of alarm behaviour in the honeybee: informational plethora of the sting apparatus signal. In: Africanized Honey Bees and Bee Mites (Needham GR, ed), Horwood, Chichester, 141-148

Boch R, Rothenbuhler WC (1974) Defensive behaviour and production of alarm pheromones in honeybees. $J$ Apic Res 13, 217-221

Brown MB, Forsythe AB (1974) Robust tests for the equality of variances. J Am Stat Assoc 69, 364-367

Collins AM, Brown MA, Rinderer TE, Harbo JR, Tucker KW (1987) Heritabilities of honey-bee alarm pheromone production. $J$ Hered $78,29-31$ 
Collins AM, Rinderer TE, Daly HV, Harbo JR (1989) Alarm pheromone production by two honeybee (Apis mellifera) types. J Chem Ecol 15, 1747-1756

Cornuet JM, Daoudi A, Mosshine EH, Fresnaye J (1988) Étude biométrique de populations d'abeilles Marocaines. Apidologie 19, 355-366

Cornuet JM. Fresnaye J (1989) Étude biométrique de colonies d'abeilles d'Espagne et du Portugal. Apidologie 20, 93-101

Cornuet JM, Garnery L (1991a) Genetic diversity in Apis mellifera. In: Diversity in the Genus Apis (Smith DR, ed) Westview, Boulder, 103-115

Cornuet JM, Garnery L (1991b) Mitochondrial DNA variability in honeybees and its phylogeographic implications. Apidologie 22, 627-642

Falconer DS (1989) Introduction to Quantitative Genetics. Longman, Harlow

Garney L, Cornuet JM, Solignac M (1992) Evolutionary history of the honey bee Apis mellifera inferred from mitochondrial DNA analysis. Mol Ecol 1, 145-154

Garnery L, Mosshine FH, Oldroyd BP, Cornuet JM (1995) Mitochondrial DNA variation in Moroccan and Spanish honey bee populations. Mol Ecol 4, 465-471

Goetze GKL (1964) Die Honigbiene in natürlicher und künstlicher Zuchtauslese. Parey, Hamburg

Hepburn HR, Jones GE, Kirby R (1994) Introgression between Apis mellifera capensis Escholtz and Apis mellifera scutellata Lepeletier: the sting pheromones. Apidologie 25, 557-565

Kerr WE (1992) Abejas Atricanas su introduccion y expansion en el continente americano. Subespecies y ecotipos Africanos. Indust Apic No 13, 12-21

Lachenbruch P, Mickey RM (1968) Estimation of error rates in discriminant analysis. Technometrics 10, 111
Lebdi-Grissa K, M'Sadda K, Cornuet JM, Fresnaye J (1991) Relations phylogénétiques de l'abeille tunisienne $A$ m intermissa avec les races d'abeilles voisines africaines et ouest méditerranéennes. $R e v$ Agric 44, 1231-1238

Mardia KV, Kent JT, Bibby JM (1979) Multivariate Analysis. Academic Press, London

Miller R (1981) Simultaneous Inference 2nd Edition. Springer, New York

Moritz RFA, Hillesheim E (1985) Inheritance of dominance in honeybees (Apis mellifera capensis Esch). Behav Ecol Sociobiol 17, 87-89

Moritz RFA, Kauhausen D (1984) Hybridization between Apis mellifera capensis and adjacent races of Apis mellifera. Apidologie 15, 211-221

Moritz RFA, Southwick EE (1992) Bees as Superorganisms. Springer, Berlin

Orantes-Bermejo FJ, Garcia-Fernandez P (1995) Morphological variability of Apis mellifera iberica in different apiaries of southern Spain. J Apic Res 34, 2330

Radloff SE, Hepburn HR, Robertson MP, van Hille R, Davidson Z, Villet MH (1996) Discriminant analysis of the honeybee populations of southwestern Africa. Afr Entomol 4, 1-6

Ruttner F (1988) Biogeography and Taxonomy of Honeybees. Springer, Berlin

Smith DR, Palopoli MF, Taylor BR, Garnery L, Cornuet JM, Solignac M, Brown WM (1991) Geographical overlap of two mitochondrial genomes in Spanish honeybees (Apis mellifera iberica). J Hered 82, 96100

Smith DR, Glenn TC (1994) Allozyme polymorphisms in Spanish honey bees (Apis mellifera iberica). J Hered 86, 12-16 